\title{
Corporate Social Responsibility and Family Firms
}

\author{
Dan Li \\ Sichuan University, No.24 in South Section of First Ring Road, Wu Hou District, Cheng Du, China \\ lidanal@163.com
}

Keywords: Corporate social responsibility, Family firms, Corporate governance, Firm value.

\begin{abstract}
Corporate Social Responsibility (CSR) has been a topical issue in recent years because of the more and more serious problems that global corporations' operations cause to the global natural environment and community. It is premature to get any definite conclusion as of the relationship or association of corporation social responsibility with corporate governance and firm value. Especially for family firms, whose nature and functioning has been paid relatively less attention to by the investors. But we think the research of the corporate social responsibility undertaking situation of family firms is meaningful. In our paper, the relationship between corporate social responsibility and variables of corporate governance, corporate reputation and financial performance will be tested.
\end{abstract}

\section{Introduction}

Corporate Social Responsibility (CSR) has been a topical issue in recent years because of the more and more serious problems that global corporations' operations cause to the global natural environment and community. Even though the corporate social responsibility has been paid a lot of attention by the global public and there has been many scholars doing research about this CSR topic, it is still premature to get any definite conclusion as of the relationship or association of corporation social responsibility with corporate governance and firm value. Especially for family firms, whose nature and functioning has been paid relatively less attention to by the investors, analysts and scholars (de Ia Cruz DénizDeniz, M. and Suarez, M. 2005), the social responsibility is somehow neglected since the family firms are more likely to focus on their economic benefits which is closely relative to their survivals in the jungle of competitive business world. Also the research about the CSR undertaking situations of family firms is not so much that any systematic funding has been discovered.

But we think the research of the corporate social responsibility undertaking situation of family firms is meaningful. First, family firms actually take a major part in the world economies (Wen, G. and Zheng, X. 2010). Especially in the US, the top 100 family business in 2010 generated about $11 \%$ of the whole country's GDP, which is $\$ 1.6$ trillion generated by the US top 100 family businesses to America's \$14.6 trillion GDP in 2010 according to CampdenFB's ranking list article, "Top 100 family businesses in North America"

The family firms' company size, the extent of family's control and involvement into the firm operation, the corporate governance and the financial or reputational situation can affect the orientation of the firm towards its CSR undertaking. The unique social interrelations, along with dynamics between the business and family can also affect its CSR decisions and behaviours (de Ia Cruz DénizDeniz, M. and Suarez, M. 2005). Among all these factors, the corporate governance of family firms, the financial situation and the reputation will be researched further. Overall, the family firms with relatively effective corporate governance, good financial performance and good reputation in the local region or the world will have a good performance in undertaking corporate social responsibilities. And we will use a regression model to check and analyze the association of different measures for these three factors with the CSR of the family firm, which is measured by scores gained from the Kinder, Lydenberg and Domini's (KLD) Stats database.

\section{Literature Review}

The relationship between corporate governance and corporate social responsibolity has become a hot research topic in past decades. Although past several years' research, the relationship between CSR and CG is still far from clear. Both corporate social responsibility and corporate governance are important mechanisms for company to successfully its operation. The objectives of CSR and 
CG are not disparate; they could act as tools for reaching similar goals. According to Kolk and Pinkse (2010), for corporate governance, there is an increasing trend not only focusing on board composition and behavior, auditor independence and risk management but also focusing on voluntary aspects of social and stakeholder responsibilities. Robertson (2009) argued that 'CSR is unlikely to be achieved without corporate transparency and disclosure and is predicated on communication with and fair treatment of all stakeholder groups'. In terms of the nature relationship between CSR and CG, Arora and Dharwadkar (2011) collected data of 518 firms of S\&P 500 and analyzed these firms' KLD. It indicated strong evidence that corporate governance would have an impact on corporate social responsibility and good governance mechanism can reduce the negative aspects of corporate social responsibility. Based on the previous literatures demonstrating that corporate social responsibility and corporate governance are not separate concepts, S.Young, V. Thyil (2014) deeply explore the link between CSR and CG and how institutional systems and other contexts influence this relationship. They concluded that CSR is a component of corporate governance and its relationship with corporate governance depends on national contexts and environmental conditions. These contexts include the economic environment, regulation and national governance system.

Finally, we review the literature about how CSR is measured and the relationship between CSR and family firms. According to Margarita Tsoutsoura (2004), there are two measurements. First is the data from corporate disclosures and CSR reports. However, there is no evidence to show whether these data from CSR reports are reported properly since few companied have their SCR reports externally verified. Second measurement is Kinder Lydenberg Domini (KLD) rating system where each company listed in the S\&P 500 is rated based on different aspects of corporate social performance. In terms of the relationship between CSR and family firms, some researchers have implied that family firms are less likely to perform its social responsibility while others have suggested that social responsibility can protect the family's assets. According to W. Gibb Dyer, Jr. David A. Whetten (2006), they collected the data of 261 firms (202 non-family firms 59 family firms) listed in the S\&P 500 and compared the degree to which family and non-family behave social responsibly. They concluded that family firms are more socially responsible than non-family firms.

\section{Hypothesis Development}

In our paper, the relationship between corporate social responsibility and variables of corporate governance, corporate reputation and financial performance will be tested. This relationship may involve mixed results - positive, negative and neutral. In order to better understand and analyze these specific relationships, we make three hypotheses based on our three variables and illustrate the reasons why we make such hypotheses.

\section{The Vision of CSR Concept in This Paper}

According to the introduction of the concept development of CSR above, we think it is appropriate to take the broader vision of CSR since all corporations are really citizens in our society by their activities having influences to others and the whole society's operations. The ultimate aim of any corporation, let alone family firms, is to maximize the interest of all the stakeholders, not only the shareholders.

Even though shareholders are a part of the stakeholders and their interests is actually one of the company's essential goals, it is impossible for any shareholder to gain any benefit if the company cannot continue to operate because of the striking of employees, the accusing complaints of customers, the noncooperation of business partners which include the suppliers and the changed environment which is not fit for human habitation any more. So you can never think shareholders' interests without the other stakeholders' interests because of the indivisible interrelations between shareholders and other stakeholders. And in the long run, the sustainability must be gained for the corporations' development by dealing with a good CSR problem.

\section{The Association between Family Firms' CSR and Corporate Governance}

In essence or overall, it is appropriate to think that family firms with effective corporate governance tend to undertake more social responsibility, since effective corporate governance will lead to the better alignment of managers' interests and shareholders' interests which will facilitate the realization of firm value which include the economic, social and environmental values under the 
broader vision of CSR concept. Besides that, good corporate governance means that the choices and activities which are unethical and illegal or which can bring too high risk to the firms' operations can be avoided so that the family firms can gain the base of undertaking CSR no matter in the ethical and legal level or in the financial level.

However, there would be some exceptions of the positive association between CSR and corporate governance. Since corporate governance can be influenced by different factors and can be checked using different measures, it is necessary to check the specific characteristic that leads to good corporate governance for some initiative may actually impeded CSR undertaking. Overall, we assume that the well governed family firm will have good performance in CSR undertaking and CSR engagement can positively influence firm value even though there are some literatures saying the impact of corporate governance is weak on the family firm's CSR choices (Jo, H. and Harjoto, M. 2011).

\section{The Association between Family Firms' CSR and Reputation}

The relationship between corporate social responsibility and corporate reputation is positive. Good corporate reputation can motivate companies to better perform its corporate social responsible; Bad corporate reputation can either motivate to behaviourally social responsible or exacerbate to pursue some irresponsible activities.

In the increasing competitive market, as companies pursue the financial performance such as revenue, market share and growth, managing corporate reputation has become a significant factor for companies to perform successfully. Before we make the above hypothesis, we should understand the benefits to the corporate with good reputation. Furthermore, with good reputation, stakeholders will support the organization even though this organization is faced with controversy. Usually companies would communicate their social responsibility through interactive media and there is a finding (Eberle,D., Berens, G., Li Ting, 2013) showing that using interactive channels to demonstrate CSR can improve corporate reputation. For those companies who do not have good reputation currently, they may choose to rebuild their reputation to pursue some positive activities which demonstrate its social responsibility; or they would ignore its reputation and give up social responsibility since it is costly to perform corporate social responsibility.

\section{The Association between Family Firms' CSR and Financial Performance}

Although to perform corporate social responsibility, companies need to invest a lot. For example, to reduce the pollution to the environment, the company may replace the existing equipment which emits many pollutants with eco-friendly equipment. This will cost a company a lot. However, from a long-term perspective, the actual costs of performing corporate social responsibility can be covered by the benefits. These benefits involve many aspects. For example, it can free the company from paying some unnecessary fees such as fees paid because of excessive pollutants, fees paid because of lawsuit. Also it can protect companies from experiencing some social negative events that would be destructive to their business. Therefore, to avoid some unnecessary expenses, companies would not conduct some irresponsible behaviour. Instead, they would carefully conduct responsible behaviours. From the other perspective, just because of companies' good fanatical performance, they would be willing to be engaged in more positive activities to communicate its corporate social responsibility.

\section{Methodology}

\section{Sample Selection}

This paper focuses on family firms; however, it is hard to give a sepcific definition of family firm. Some researches define family firm based on its ownership and control. Specifically, a family firm is a firm that family members control significant voting rights or ownership (Barnes and Herson, 1976). Another criterion is the number of family members in corporate management. More recently, some scholars have claimed family firms with the minimum threshold of family members owning $20 \%$ of the capital (Villalonga and Amit, 2006).

In this paper, we select top 100 family firms in North America which generating approximately \$1.6 trillion to America's \$14.6 trillion GDP in 2010 ( Campden FB, 2011). We use the data of 
these family firms from 2003 to 2013. All the familt firms on the list must meet these criteria: (1) There is at least one family member involves in corporate governance. (2) If a family member or members own $25 \%$ of decision-making rights mandated by their share capital. 3) The shares controlled by the family is at least in the second generation or beyond (Campden FB, 2011).

Among the list, the biggest supermarket chain Walmart ranks the top with more than $40 \%$ owned by Walton family. The first Canadian company on the list is the retailer George Weston, controlled by the Weston family, which had revenues of $\$ 32$ billion last year. Aother feature of this list is that most of these family firms are related to food. The following table is the list of top 100 family firms in North America.

Tab. 1

\begin{tabular}{|c|c|c|c|c|}
\hline Walmart & Reyes Holdings & McCain Foods & $\begin{array}{l}\text { Hyatt Hotels } \\
\text { Corporation }\end{array}$ & $\begin{array}{l}\text { American Financial } \\
\text { Group }\end{array}$ \\
\hline Ford & Thomson Reuters & Saputo & Grocers Supply & Jean Coutu Group \\
\hline Cargill & Enterprise Holdings & $\begin{array}{l}\text { Wegmans Food } \\
\text { Markets }\end{array}$ & Belk & $\begin{array}{l}\text { WL Gore and } \\
\text { Associates }\end{array}$ \\
\hline $\begin{array}{c}\text { Koch } \\
\text { Industries }\end{array}$ & Fidelity Investments & $\begin{array}{c}\text { Meadowbrook Meat } \\
\text { Company }\end{array}$ & Walsh Group & EllisDon \\
\hline Comcast & $\begin{array}{c}\text { Rogers } \\
\text { Communications }\end{array}$ & Maple Leaf Foods & Hearst Corporation & $\begin{array}{l}\text { Asplundh Tree } \\
\text { Expert Company }\end{array}$ \\
\hline News Corp & $\begin{array}{c}\text { Marriott } \\
\text { International }\end{array}$ & RaceTrac & $\begin{array}{c}\text { Molson Coors } \\
\text { Brewing Company }\end{array}$ & Milliken and Co \\
\hline $\begin{array}{l}\text { George } \\
\text { Weston }\end{array}$ & Canadian Tire & Kelly Services & Brown-Forman & Foster Farms \\
\hline Mars & Cumberland Farms & $\begin{array}{c}\text { The Washington Post } \\
\text { Company }\end{array}$ & Raley's supermarkets & $\begin{array}{c}\text { Young's Market } \\
\text { Company }\end{array}$ \\
\hline Tyson Foods & Nordstrom & Perdue & E \& J Gallo Winery & Ebsco Industries \\
\hline $\begin{array}{l}\text { Bechtel } \\
\text { Group }\end{array}$ & $\begin{array}{l}\text { JM Family } \\
\text { Enterprises }\end{array}$ & JR Simplot Company & Holiday Companies & Wilbur-Ellis \\
\hline $\begin{array}{l}\text { Publix Super } \\
\text { Markets }\end{array}$ & $\begin{array}{l}\text { Huntsman } \\
\text { Corporation }\end{array}$ & Sheetz & Schneider National & Fry's Electronics \\
\hline $\begin{array}{c}\text { C\&S } \\
\text { Wholesale } \\
\text { Grocers }\end{array}$ & Amway & Levi Strauss & Gilbane & Plastipak Holdings \\
\hline Bombardier & $\begin{array}{l}\text { SC Johnson and } \\
\text { Son }\end{array}$ & Kohler & Rich products & $\begin{array}{l}\text { Hunt Construction } \\
\text { Group }\end{array}$ \\
\hline Love's & $\begin{array}{l}\text { Gordon Food } \\
\text { Service }\end{array}$ & $\begin{array}{c}\text { James Richardson \& } \\
\text { Sons }\end{array}$ & Drummond Company & $\begin{array}{c}\text { JE Dunn } \\
\text { Construction Group }\end{array}$ \\
\hline $\begin{array}{l}\text { HE Butt } \\
\text { Grocery }\end{array}$ & Giant Eagle & Hallmark Cards & Follett Corporation & $\begin{array}{c}\text { Day \& Zimmermann } \\
\text { Group }\end{array}$ \\
\hline $\begin{array}{l}\text { Empire } \\
\text { Company }\end{array}$ & Menards & Cascades & Amkor Technology & Zachry Corporation \\
\hline Gap & $\begin{array}{l}\text { Estee Lauder } \\
\text { Companies }\end{array}$ & Dot Foods & Swift Transportation & EA Fish Companies \\
\hline $\begin{array}{c}\text { Loews } \\
\text { Corporation }\end{array}$ & $\begin{array}{c}\text { Advance } \\
\text { Publications }\end{array}$ & Gulf States Toyota & Alex Lee & American Greetings \\
\hline $\begin{array}{c}\text { Cox } \\
\text { Enterprises } \\
\end{array}$ & Jim Pattison Group & Golub Corporation & $\begin{array}{c}\text { The Lefrak } \\
\text { Organization } \\
\end{array}$ & Valhi \\
\hline Meijer & Carlson Company & Shaw Communications & Schnuck Markets & 84 Lumber \\
\hline
\end{tabular}




\section{Regression Model}

According to the analysis made above, we would use the regression model as following:

$$
\text { CSR of family firms }=a * X 1+b * X 2+c * X 3+d * X 4+e^{* X} 5+f * X 6+\varepsilon
$$

In this paper, the CSR undertaking situation will be measured by the CSR scores which can be found in the Kinder, Lydenberg and Domini's (KLD) Stats database. The data in KLD gives out the ratings of different CSR indexes or indicators with each of them corresponding to a specific CSR characteristic such as percentage of female employees, number of days in maternity leave for both female and male employees and volume of a specific pollutant discharged. Actually this characters are categorized into five criteria-product, diversity, community, environment and employee relations in KLD (Jo, H. and Harjoto, M. 2011) complying with the classification of Global Report Initiative, a non-for-profit organization which is committed to providing normalization of corporate social responsibility report. Since the CSR scores given by KLD include the strength and concern rating, we will accumulate the strength ones and minus the weakness ones and get a total score for each firm.

The variables $\mathrm{X} 1, \mathrm{X} 2, \mathrm{X} 3$, and $\mathrm{X} 4$ will be the indicators which are used to measure corporate governance. We would get the relevant data from RiskMetrics database, CDA/Spectrum 13(f) filings and Institutional Brokers Estimation Services database since the measures of corporate governance in KLD have different dimension of definition from the common governance measures. Then X1 will represent board independence of a family firm, which is measured by the proportion of outside independent directors. X2 represents the institutional ownership which is measured by proportion of institutional holdings. X3 will reflect the situation of analyst following, which is represented by the number of security analyst following the firm. X4 measures the anti-takeover provisions by the number of provisions. Actually the board leadership can also be used as one of the measures that reflect the corporate governance. But it is very difficult to quantify this measure, so we neglect it in our regression model.

$\mathrm{X} 5$ is the variable that reflects the financial value of the family firm. One of the most frequently used firm value measures - the Tobin's q will be used as our measure of the variable X5.

X6 will be the reputation indicator which will be measured by the Fortune ranking number. But we will use the number of (500- the number) as our number in the equation. And any family firm who is not in the ranking list will be measured as a (-1).

In the next step we will collect all the data of the databases into an Excel Worksheet and run the regression analysis to get the final result which will show the information about all the coefficients. And then we will use the completed result of the regression model to make further analysis and to check whether the data results are consistent with our theoretically inferential analysis along with the assumptions and hypotheses in the previous part of this paper.

\section{References}

[1] Cochran, P. L., and R. A. Wood (1984) "Corporate social responsibility and financial performance.” Academy of Management Journal, 27 (1): 42 -56.

[2] Jo, H., \&Harjoto, M. (2011). Corporate Governance and Firm Value: The Impact of Corporate Social Responsibility. Journal Of Business Ethics, 103(3), 351-383. doi:10.1007/s10551-011-0869-y.

[3] Wen, G., \&Zheng, X. (2010). The analysis of family business' corporate social responsibility and its sustainable by system archetype.IEEE International Conference On Advanced Management Science (ICAMS), 2010, 121. doi:10.1109/ICAMS.2010.5553042.

[4] Eberle,D., Berens, G., Li Ting (2013) "The Impact of Interactive Corporate Social Responsibility Communication on Corporate Reputation.” J Bus Ethics (2013) 118:731-746. 
[5] Jean, B.M., Alison, S., Thomas, S. (1988) "Corporate Social Responsibility and Firm Financial Perfoemance.” Academy of Management Journal,1988, Vol. 31, No. 4, 854-872.

[6] Margarita Tsoutsoura (2004) "Corporate Social Responsibility and Financial Performance." University of California at Berkeley Financial Project.

[7] S.Young, V. Thyil (2014) "Corporate Social Responsibility and Corporate Governance:Role of Context in International Settings.” J Bus Ethics (2014) 122:1-24.

[8] W. Gibb Dyer, Jr. David A. Whetten (2006). "Family Firms and Social Responsibility Preliminary Evidence from the S\&P 500." Entrepreneurship Theory and Practice (2006) November.pp:785-802. 